\title{
Generációváltás és nemzetközi teljesítmény a hazai regionális tudományban
}

\section{Generational change and international performance in Hungarian regional science}

\author{
LENGYEL BALÁZS
}

\begin{abstract}
LENGYEL Balázs: vezető kutató, Közgazdaság- és Regionális Tudományi Kutatóközpont, Agglomeráció és Társadalmi Kapcsolathálózatok Lendület Kutatócsoport; 1097 Budapest, Tóth Kálmán u. 4.; lengyel.balazs@krtk.mta.hu; https://orcid.org/0000-0001-5196-5599

KULCSSZAVAK: fiatal regionalisták; doktori képzés; nemzetközi publikáció
\end{abstract}

Balázs LENGYEL: Head, Agglomeration and Social Networks Lendület Research Group, Centre for Economic and Regional Studies; Tóth Kálmán u. 4., H-1097 Budapest, Hungary; lengyel.balazs@krtk.mta.hu; https://orcid.org/0000-0001-5196-5599

KEYWORDS: young regional scientists; doctoral schools; international publication

Hozzászólásomban „A hazai regionális tudományról: eredmények és kihívások” című vitairatban megfogalmazott kihívásokra kívánok reagálni. A generációváltás problémaköréből kiindulva, közvetlenül a nemzetközi kutatási élvonaltól való elmaradás kérdéseihez kapcsolódnék.

A tudományos kutatással szembeni hazai elvárások jelentősen megváltoztak az elmúlt évtizedekben. A tudományos közösség egyre inkább az alapkutatási eredmények nemzetközi megjelenését díjazza, ami a kutatási pályázatok elbírálásában és sikerességében is tükröződik. A regionális tudomány fiatal generációjának elsősorban ezeknek az új elvárásoknak kell megfelelnie. Meggyőződésem szerint a nemzetközi szinten mérhető teljesítmény mint elvárás alapvetően meghatározza a regionális tudomány új generációjának karrierjét, és ezen keresztül a közösségünk jövőjét. Ezért elengedhetetlen, hogy jobban ösztönözzük és segítsük a fiatalokat a nemzetközi teljesítmény elérésében.

Mindenekelőtt ki kell emelnem, hogy a kiszámítható kutatói és oktatói életpálya, a magas képzettséget megillető bérezés elengedhetetlen ahhoz, hogy tehetséges fiataljaink a pályán maradjanak és a hazai regionális tudományt erősítsék. A kutatói és oktatói bérek problémája szétfeszítené a hozzászólás kereteit, ugyanakkor nem mehetünk el azon probléma mellett, hogy a nemzetközi teljesítményt elérő, elsősorban elemzői készségekkel bíró fiatalok megugró fizetésre számíthatnak akár a hazai vállalati szektorban, akár a külföldi tudományos munkatársi állásokban. El kell érnünk, hogy a nemzetközi cikkeket

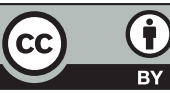


publikáló kutatók és oktatók nemzetközi szinten is versenyképes fizetést kapjanak itthon.

A nemzetközi teljesítmény növelése érdekében a tudományos karriert célzó fiataloknak már a doktori képzés alatt meg kell tanulniuk, hogy miként kell az elismert nemzetközi folyóiratokban publikálni, vagy ehhez mérhető szintű munkát végezni. Ugyanakkor a számos doktori iskolában alkalmazott publikációs pontrendszer, illetve a disszertációhoz kapcsolódó követelmények nem ösztönöznek ilyen teljesítményre. Az alábbi kapcsolódó problémákat látom:

- A doktori.hu és az MTMT adatbázisokon alapuló saját elemzéseim szerint azok a fiatal kutatók lesznek elismertek (a hivatkozások számával mérve) a pályázati életkoruk elérésekor (6-8 évvel a doktori védés után), akik doktori tanulmányaik alatt kevés tanulmányt publikálnak, viszont a védésüket megelőző vagy közvetlenül követő időszakban nagy hatású (sokat hivatkozott) írásaik jelennek meg. Ezért azok a doktorandusz fiatalok, akik a pontrendszernek több kisebb tanulmánnyal felelnek meg, és nem igyekeznek nagyobb hatású, nemzetközi folyóiratok szintjét elérő tanulmányt publikálni, kettős csapdahelyzetbe kerülnek. Egyrészt kicsi az esély arra, hogy pályázati forrásokért versenyezni tudjanak a sok hivatkozással bíró kollégáikkal. Másrészt a későbbi karrierjük során tovább csökken a tanulás lehetősége, így annak valószínűsége is, hogy ki tudjanak ugrani a kutatási pályázatokon.

- A disszertációkkal szemben támasztott általános követelmények, véleményem szerint, túl nagy terhet rónak azokra a doktorjelöltekre, akik nemzetközi folyóiratokban publikálnak. A folyóiratok lektorainak megfelelni általában nehéz, sok időt igénylő folyamat, amelyben mind elméleti, mind módszertani szempontból a világ élvonalához kell alkalmazkodni. A klasszikus könyvszerű disszertáció feladata az ilyen hallgatók esetében nem időszerü, hiszen a hallgatónak bőven elég a feladat, hogy a nemzetközi cikkeket megírja.

Azt gondolom, hogy növelné a fiatal regionális tudományi generáció által írt nemzetközi cikkek számát, ha az ilyen tanulmányokat készítő doktorjelöltek esetében alternatív követelményeket támasztanának a doktori iskolák pontrendszere helyett, illetve ha a hallgatók készíthetnének cikkeket összefüző disszertációt, jellemzően angol nyelven.

Kiemelkedő folyóiratokban publikálni nehéz, különösen az első alkalmakkor. A fiatal kutatók, néhány kivételes tehetségtől eltekintve, ezt akkor tudják teljesíteni, ha tapasztalt kollégával dolgoznak együtt, aki már publikált ilyen helyeken és képes átadni tudását. Úgy gondolom, hogy kihasználhatnánk a hazai regionális tudományi közösség összetartó közegét, és mélyíthetnénk a fiatalok közötti együttműködést. Egyre bővül ugyanis azoknak a fiataloknak a köre, akik publikáltak már kiugró nemzetközi folyóiratokban. Érdemes volna felkérni őket a regionális tudomány intézményei (MRTT, MTA RTB) kereteiben zajló új programon 
belül, hogy indítsanak közös kutatásokat a hozzájuk témában közel álló, de más műhelyben dolgozó fiatal kollégákkal.

Úgy vélem, hogy a nemzetközi cikkek számának növeléséhez elengedhetetlen a módszertani ismeretek széles körben való erősítése. A tudományos mühelyek jellemzően specializáltak, ezért több országban is kialakult gyakorlat, hogy a PhD-hallgatók a doktori iskolák közös rendezésű nyári egyetemein jutnak magas szintü ismeretekhez. Érdemes volna olyan új nyári egyetemet kezdeményezni, ahol a hazai és környező országokból érkező PhD-hallgatók kimondottan a regionális tudományi (kvalitatív és kvantitatív) módszerekre koncentrálnának. Ezek a képzések nemcsak számos kutatást segíthetnének, de erősíthetnék a fiatalok nemzetközi kapcsolatait is. 